\title{
PENGOLAHAN KAIN PERCA MENJADI SEKAT PEREDAM SUARA
}

\section{Processing Patchwork into Sound Insulation Partition}

\author{
Patricia Pahlevi Noviandri $^{1}$ dan Centaury Harjani ${ }^{2}$ \\ ${ }^{1}$ Program Studi Teknik Arsitektur Universitas Kristen Duta Wacana \\ patriciapahlevi@staff.ukdw.ac.id \\ ${ }^{2}$ Program Studi Desain Produk Universitas Kristen Duta Wacana \\ Centaury.h@gmail.com
}

Tanggal masuk: 5 Oktober 2016

Tanggal revisi: 14 Desember 2016

Tanggal disetujui: 22 Desember 2016

\begin{abstract}
ABSTRAK
Permasalahan sampah di Indonesia sangat tinggi. Sebanyak 2\% dari total sampah di Indonesia berasal dari kain. Limbah kain tersebut dapat diolah menjadi produk yang bernilai ekonomis. Berbagai macam produk limbah kain diantaranya tas, selimut, sandal, tatakan meja, maupun keset mampu bersaing dengan produk dari industri besar. Pengolahan limbah kain yang ingin diangkat oleh penelitian ini adalah limbah kain sebagai sekat ruangan. Sekat ruangan yang bersifat temporer untuk rumah tinggal saat ini diindikasi mampu untuk memisahkan ruang secara visual namun tidak mampu memisahkan suara antar ruang yang satu dengan yang lain. Penelitian ini bertujuan mendapatkan olahan bahan kain yang efektif meredam suara dengan metode eksperimen. Pengujian dilakukan dengan menggunakan beberapa sampel dengan tiap sampel diuji dengan beberapa tingkat bunyi (125 $\mathrm{Hz}$ hingga $2000 \mathrm{~Hz}$ ). Variabel pembeda sampel berupa material sekat yaitu kain perca berbahan denim dan kain perca berbahan katun. Manfaat penelitian ini yaitu mendapatkan desain partisi yang memenuhi aspek keindahan untuk dekorasi ruang dan memenuhi aspek akustik sebagai peredam suara tingkat rumah tinggal. Hasil dari penelitian ini yaitu olahan kain perca berupa gempal yang efektif meredam suara dan memberikan motif dekorasi yang unik. Kemampuan sekat berbahan kain perca ini dalam meredam suara sebesar $6 \mathrm{~dB}$ sampai $15 \mathrm{~dB}$ dilihat dari nilai tingkat penurunan kebisingannya. Olahan kain perca dapat meredam suara pada frekuensi yang dihasilkan oleh suara manusia $(<2000 \mathrm{~Hz})$.
\end{abstract}

Kata kunci: Partisi, Peredam Suara, Kain Perca, Sekat.

\section{ABSTRACT}

The waste problems in Indonesia are very high. As many as $2 \%$ of the total waste in Indonesia comes from the fabric. The fabric waste can be processed into products with high economic value. A variety products from fabrics waste processing are bags, blankets, slippers, placemats table, as well as doormats are able to compete with big industries products. This research propose in processing fabric waste into a soundproof room partition. Room partition available now is indicated able to separate room visually, but not soundproofing between room. This study aim is to get a processed fabric whic is effective in decreasing the noise with the experimental method.The tests is carried out using multiple samples with each sample are given some degree of sound (125 Hz to $2000 \mathrm{~Hz})$. The variety in sample is of material from denim patchwork and cotton patchwork. The benefits of this research is a room partition design that meets the beauty aspect of room decoration and the acoustic aspect in residential scope. The results of this research are processed patchwork stocky which are effective to reduce noise and provide a unique decorative motif. The ability of processed patchwork partition in reducing noise is by $6 \mathrm{~dB}$ to $15 \mathrm{~dB}$ seen from the noise reduction levels. Processed patchwork can reduce the sound at a frequency that is produced by the human voice $(<2000 \mathrm{~Hz})$.

Keywords: partition, sound insulation, patchwork 


\section{PENDAHULUAN}

Data statistik dari Kementerian Negara Lingkungan Hidup Indonesia pada tahun 2008 menunjukan bahwa jumlah timbunan sampah di Indonesia tinggi (KNLH, 2008). Data tersebut merupakan estimasi sampah di Indonesia selama lima tahun dalam rentang tahun 2003-2008,seperti ditampilkan pada Tabel 1. Tabel 2 menunjukan estimasi jenis sampah yang tertimbun di seluruh Indonesia dalam rentang tahun 2003-2005.

Tabel 1. Estimasi Total Timbulan Sampah Seluruh Indonesia (KNLH, 2008)

\begin{tabular}{|lc|}
$\begin{array}{c}\text { Kelompok } \\
\text { Wilayah }\end{array}$ & $\begin{array}{c}\text { Timbulan Sampah (juta } \\
\text { ton / tahun) }\end{array}$ \\
\hline Sumatera & 8,7 \\
\hline Jawa & 21,2 \\
Balinusra & 1,3 \\
Kalimantan & 2,3 \\
\hline Sumapapua & 5,0 \\
\hline TOTAL & 38,5
\end{tabular}

Tabel 2. Estimasi Total Timbulan Sampah Berdasarkan Jenisnya (KNLH, 2008)

\begin{tabular}{lcc}
\hline \multicolumn{1}{|c}{ Jenis Sampah } & $\begin{array}{c}\text { Jumlah (juta } \\
\text { ton / tahun) }\end{array}$ & \% \\
\hline Sampah Dapur & 22,4 & 58 \\
\hline Sampah Plastik & 5,4 & 14 \\
Sampah Kertas & 3,6 & 9 \\
\hline Sampah Lainnya & 2,3 & 6 \\
\hline Sampah Kayu & 1,4 & 4 \\
Sampah Kaca & 0,7 & 2 \\
Sampah Karet / & 0,7 & 2 \\
Kulit & & \\
Sampah Kain & 0,7 & 2 \\
Sampah Metal & 0,7 & 2 \\
Sampah Pasir & 0,5 & 1 \\
\hline TOTAL & 38.5 & 100
\end{tabular}

Dari Tabel 1 terlihat bahwa terjadi penumpukan sampah di Jawa. Hal itu dikarenakan, perilaku pengolahan sampah yang belum memadai. Data mengenai kondisi perlakuan pada sampah ditampilkan dalam Gambar 1.

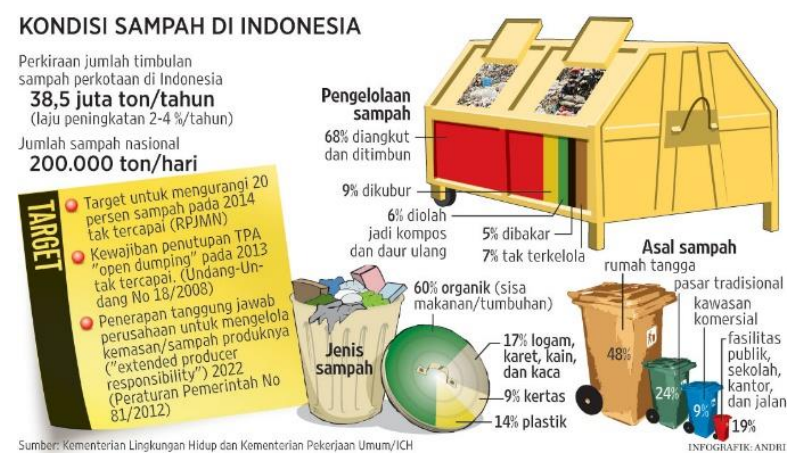

Gambar 1. Sistem Penanganan Sampah

(KNLH, 2008)

Dengan demikian jelaslah bahwa sampah masih menjadi masalah serius yang perlu ditangani. Adanya Undang Undang Nomor 18 Tahun 2008 tentang Pengelolaan Sampah semakin memperkuat alasan untuk mengolah sampah dengan kreatif.

Merujuk pada Buku Profil Bank Sampah Indonesia tahun 2012 mengenai pengolahan sampah dengan program 3R(Reduce, Reuse, Recycle) masyarakat masih perlu diajak untuk memilah dan mengolah sampah dengan benar. Karena kendala yang dihadapi saat ini adalah mengenai masyarakat yang belum peduli akan pentingnya mengelola sampah dan masyarakat belum melihat peluang ekonomis pada pengolahan tersebut. Sehingga perlu untuk melakukan penyuluhan untuk menginspirasi masyarakat, seperti yang tertulis pada buku Profil Bank Sampah Indonesia 2012 yaitu "dimana dahulu sampah dijauhi atau dimusuhi, sekarang didekati dengan mengolah dan memanfaatkannya serta menjadi Rupiah".

Konsep Green saat ini menjadi topik yang banyak dikerjakan oleh masyarakat, baik arsitek hingga desainer. Berbagai pengolahan daur ulang material maupun penghematan material banyak menjadi 
bahasan. Permasalahan yang ada mengenai kejenuhan yang ada di pasaran, seperti olahan bahan-bahan perca yang sangat banyak memiliki kemiripan. Pada penelitian ini dikembangkan produk interior yang berbeda dipasaran dengan menggunakan material kain perca yang banyak menjadi bahan sisa industri. Produk interior memiliki fungsi sebagai sekat ruangan sekaligus menjadi peredam suara antara ruangan yang satu dengan yang lainnya. Penelitian ini akan membandingkan pengolahan sisa kain perca berbahan kain katun dan kain denim yang paling efektif untuk dijadikan sekat ruangan peredam suara dilihat dari nilai penurunan intensitas bunyinya.

Merujuk pada teori Victor Papanek mengenai konsep Green dalam bukunya The Green Imperative: Ecology and Ethics in Design and Architecture, ada enam hal yang harus diperhatikan dalam mengelola produk yaitu mengenai the choice of materials, the manufacturing processes, packaging the product, the finish product, transporting the product, and waste (Papanek, 1995). Dalam penelitian ini penulis fokus pada teori Green mengenai the choice of materials, penulis memilih bahan sisa kain perca dari industri di wilayah Yogyakarta.

Mencipta suatu karya yang Green dalam artian ramah lingkungan, sebagai bentuk peduli pada lingkungan, perlu memperhatikan Product Life Cycle Assessment, yaitu melihat tahapan proses produk dari awal berupa raw material (jenis material yang digunakan maupun sumber material tersebut), proses produksi, penjualan, penggunaan produk, hingga akhir dari produk setelah selesai digunakan (Papanek, 1995). Dengan demikian membuat karya produk dari material limbah kain perca adalah salah satu penciptaan yang ramah lingkungan.
Ada banyak jenis produk perca yang berkembang selama ini, seperti:

a. Tas

Tas (Gambar 2) yang berkembang masih banyak yang berfokus pada penggunaan bahan perca kain batik. Tas Fashion mampu memadu padankan permainan warna-warni bermacam-macam kain perca dan membentuknya.

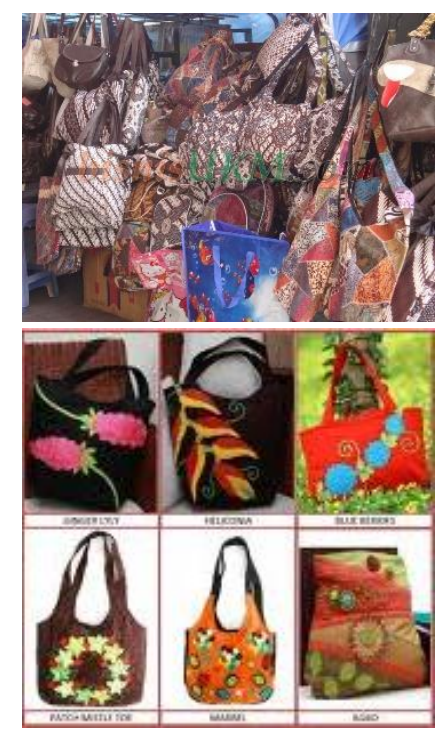

Gambar 2. Produk Tas

b. Sandal

Produk sandal (Gambar 3) ini mengkombinasikan warna dan motif kain perca, serta menggunakan teknik anyam, bukan jahit.

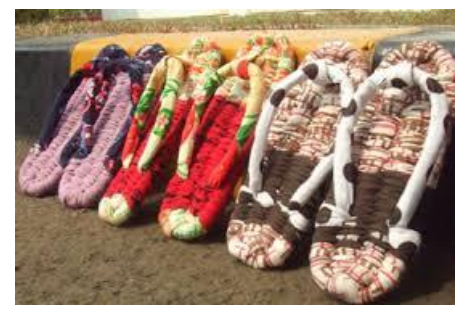

Gambar 3. Produk Alas Kaki

c. Selimut

Produk selimut (Gambar 4) menggunakan warna-warni kain yang bukan merupakan limbah sisa kain perca, melainkan kain baru yang di potong-potong yang dibuat seolah kain perca. Hal ini 
banyak dilakukan untuk memperoleh efek patchwork pada suatu produk.

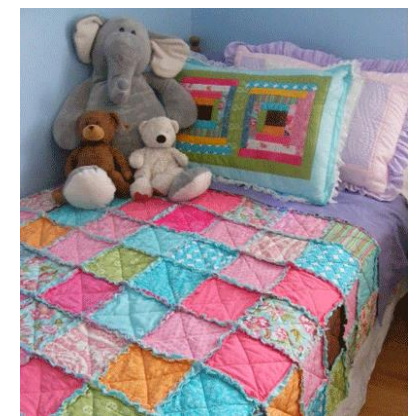

Gambar 4. Produk Selimut

d. Tatakan Meja / Keset

Produk tatakan (Gambar 5 dan 6) memanfaatkan potongan limbah kain perca, bahkan yang berukuran kecil. Pembuatannya memadukan teknik origami dan jahit (kebanyakan di atas kain belacu).

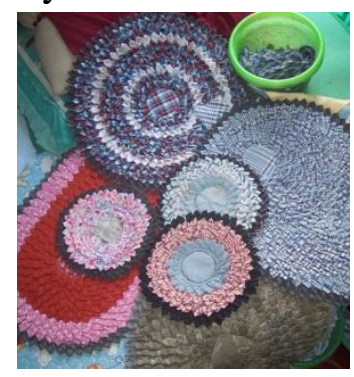

Gambar 5. Produk Tatatakan

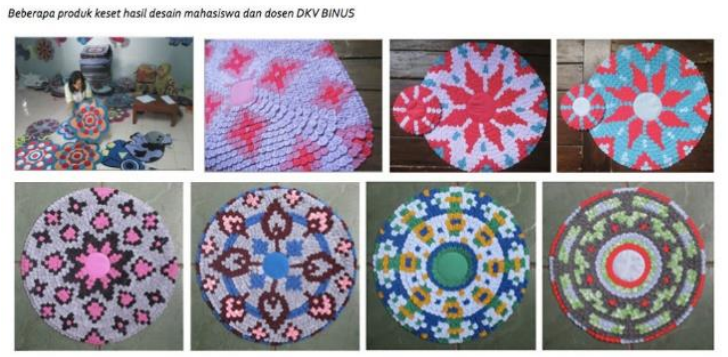

Gambar 6. Pengembangan Tatakan dan Keset (Sari Wulandari,2014)

Produk tatakan mengembangkan aspek desain visual, dengan menata warna-warni kain yang digunakan, tampilan produk ini berubah menjadi lebih elegan dan berkelas. Pemilihan teknik jahit yang tidak menggunakan origami lipat, namun jelujur pada bentuk lingkaran yang kemudian dilipat menjadi setengah lingkaran, membuat penyusunan komposisi warna menjadi lebih mudah dan akurat, sehingga produk yang dihasilkan dapat memiliki motif yang menarik. Dengan melakukan pemilihan dan komposisi warna serta teknik penjahitan yang tepat dapat mengubah tampilan suatu produk perca menjadi dramatis.

Berdasarkan produk-produk perca yang sudah beredar di pasaran masih ada peluang untuk mengembangkan pengolahan material perca dari segi visual. Teknik yang baik dapat menghasilkan produk perca dengan tingkat visual yang baik. Selain dari aspek visual pengembangan perca juga dapat dilakukan dengan pengembangan dari segi fungsionalnya. Seperti pemanfaatan material perca menjadi elemen produk interior yang lebih memiliki nilai jual. Elemen produk interior yang dapat dikembangkan misalnya sekat atau partisi yang sekaligus berfungsi sebagai peredam suara.

Dalam menjawab kebutuhan tersebut, material kain dapat digunakan sebagai partisi karena kain memiliki tingkat kedap suara yang cukup tinggi. Kualitas dari bahan penyerap suara ditunjukkan dengan nilai $\alpha$ (koefisien penyerapan bahan terhadap bunyi), semakin besar $\alpha$ maka semakin baik digunakan sebagai penyerap suara. Nilai berkisar dari 0 sampai 1 . Jika $\alpha$ bernilai 0 , artinya tidak ada bunyi yang diserap. Sedangkan jika $\alpha$ bernilai 1 , artinya $100 \%$ bunyi yang datang diserap oleh bahan. Tirai kain memiliki koefisien absorbsi sebesar 0,11 sampai dengan 0,55 tergantung dengan ketebalannya (Mediastika, 2005).

Nilai koefisien absorbsi kain yang termasuk tinggi memberikan peluang untuk membuat sekat terbuat dari gempal kain perca yang sekaligus memanfaatkan limbah industri tekstil untuk meninggikan nilainya. Gempal kain perca berarti bentuk yang memiliki tiga dimensi (panjang, lebar, dan tinggi) yang bisa diraba. 
Penelitian-penelitian mengenai material sekat/partisi/panel akustik sebelumya sudah sangat banyak. Material peredam suara dengan menggunakan kombinasi damen, serabut kelapa, dan dinding bata yang dilakukan oleh Febrian Tri SH, dkk memperlihatkan bahwa campuran serabut kelapa lebih efektif daripada damen dalam mengurangi intensitas suara (Febrian, Sugiarto, Sudjarwo, \& Buntoro, 2012). Material serat kelapa memiliki nilai koefisien absorbsi sebesar 0,98 pada frekuensi $3150 \mathrm{~Hz}$ (Eddy, 2014). Material kain denim dengan tebal $1 \mathrm{~mm}$ dan rapat massa $400 \mathrm{~kg} / \mathrm{m} 3$ memiliki absorbsi suara 0,05 - 0,1 bergantung pada tebal rongga udaranya (Nico N. S., 2007).

Dari penelitian-penelitian tersebut belum ada yang menghasilkan nilai penurunan intensitas bunyi menggunakan gempal kain. Oleh sebab itu, penelitian ini fokus pada olahan kain perca berupa gempal kain yang memiliki nilai pengurangan intensitas bunyi dari gempal kain berbahan denim maupun gempal kain berbahan katun.

\section{METODOLOGI}

Dalam pembuatan sampel untuk uji akustik, bahan dan alat yang digunakan adalah sebagai berikut : kain perca bahan katun dan bahan denim, lem kain, bingkai kayu ukuran $25 \times 25 \mathrm{~cm}$, gunting, penggaris atau meteran, jarum pentul.

\section{Pembuatan Sampel}

Mendaur ulang kain memiliki banyak jenis teknik. Teknik yang sudah banyak berkembang adalah teknik menjahit. Teknik ini biasa digunakan untuk merangkai dan membentuk kain perca menjadi aksesoris. Selain teknik jahit, ada 4 teknik sederhana yang dikembangkan oleh Priyanti (Priyanti, 2013) dalam mengolah kain perca, yaitu: teknik lem, teknik pilin, teknik lipat, dan teknik gulung. Dalam mengolah material perca untuk peredam suara (sekat) ini menggunakan teknik yang sederhana yaitu lipat, gulung dan lem untuk membentuk gempal berdiameter $2 \mathrm{~cm}$ dan tinggi $4 \mathrm{~cm}$. Kemudian akan diuji kemampuan menurunkan nilai intensitas bunyi yang terbaik. Berikut penjabaran prosesnya:

\section{Proses Pembentukan Gempal}

i. Memotong kain perca agar memiliki ukuran yang seragam

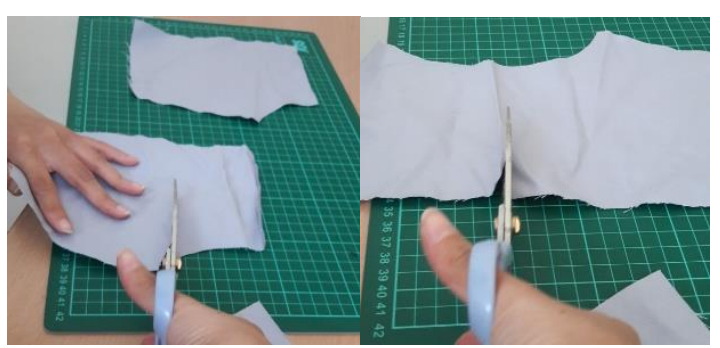

Gambar 7. Pemotongan Kain Perca

ii. Memberi lapisan rangkap dua dan melipat membentuk persegi panjang.
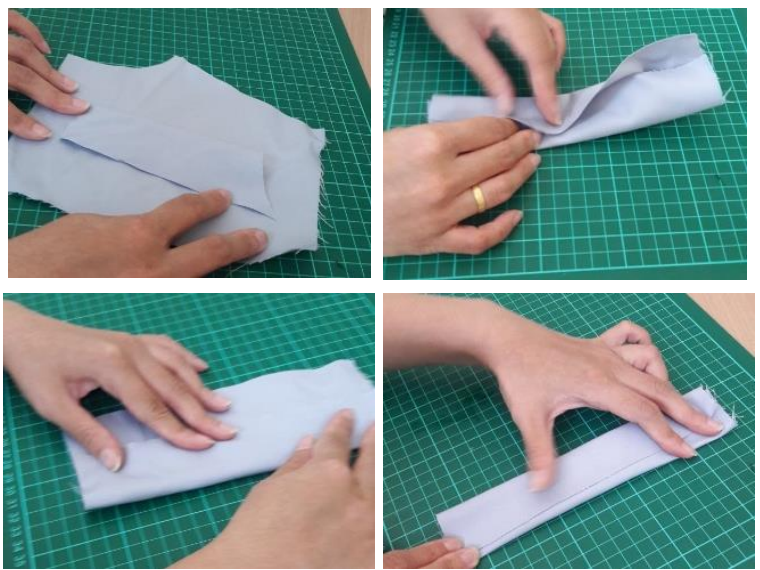

Gambar 8.Pelapisan Kain Rangkap Dua 
iii. Menggulung dari dua arah
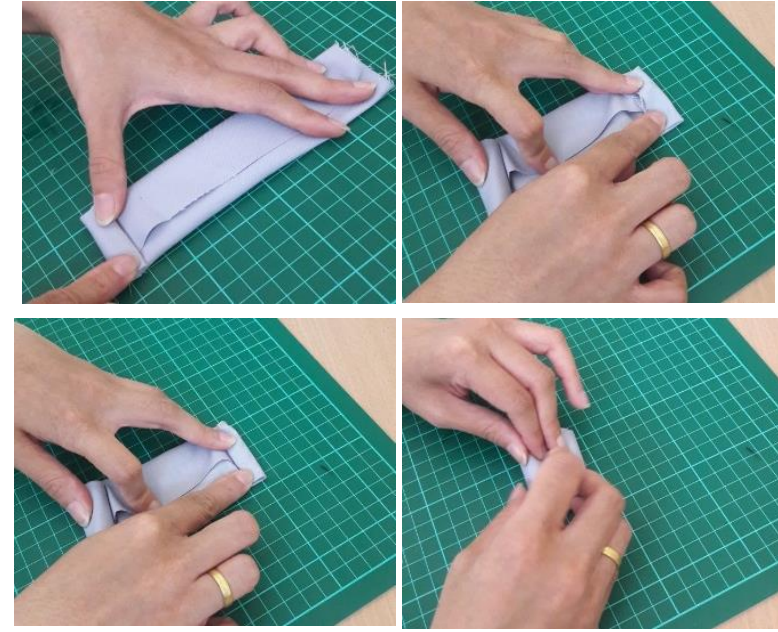

Gambar 9.Penggulungan Kain Dua Arah

iv. Merekatkan dengan Lem
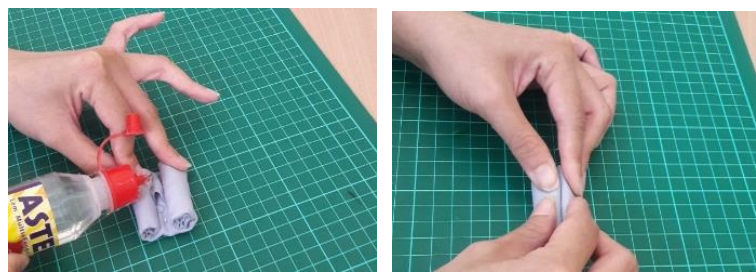

Gambar 10.Perekatan Gulungan Kain

v. Mempertahankan bentuk dengan jarum pentul

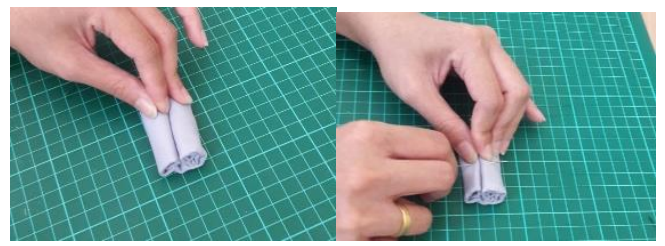

Gambar 11.Penjaruman Kain

vi. Hasil pembentukan silinder (ukuran: diameter $2 \mathrm{~cm}$ dan tinggi $4 \mathrm{~cm}$ )
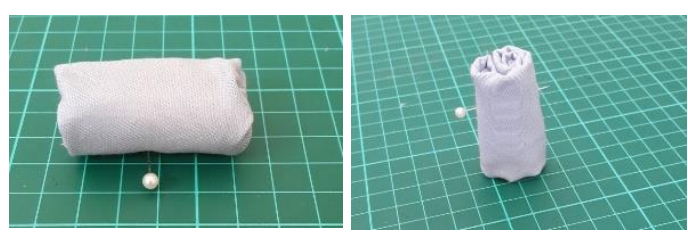

Gambar 12. Hasil Gempal Silinder
2. Contoh Variasi Perangkaian Pembentukan Motif (Dalam bingkai ukuran $25 \times 25 \mathrm{~cm}$ )
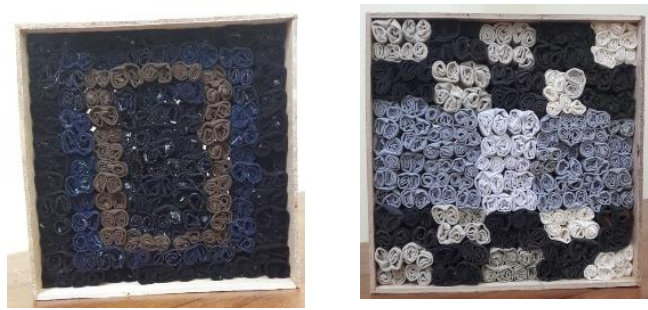

Gambar 13.Variasi Rangkaian Motif

3. Proses Pengujian Noise Reduction (NR)

Dalam memperlihatkan tingkat efektivitas sebuah produk dalam meredam suara, perlu perhitungan NR yang dibandingkan dari nilai yang dihasilkan setiap sampelnya. Perhitungannya menggunakan rumus sebagai berikut.

$$
\mathrm{NR} \quad=\text { SPL1-SPL2 } \ldots \ldots \ldots . .1
$$

Dimana :

$$
\begin{array}{ll}
\mathrm{NR} & =\text { Noise Reduction }(\mathrm{dB}) \\
\mathrm{SPL} 1 & =\text { SPL sumber bunyi }(\mathrm{dB}) \\
\text { SPL2 } & =\text { SPL penerima bunyi }(\mathrm{dB})
\end{array}
$$

(Egan, M.D., 1972)

Alat yang digunakan untuk pengukuran Noise Reduction (NR) adalah sebagai berikut :

- 2 buahSound Level Meter (SLM)

- Speaker

- Komputer

- Bidang pelingkup

- Sampel Partisi

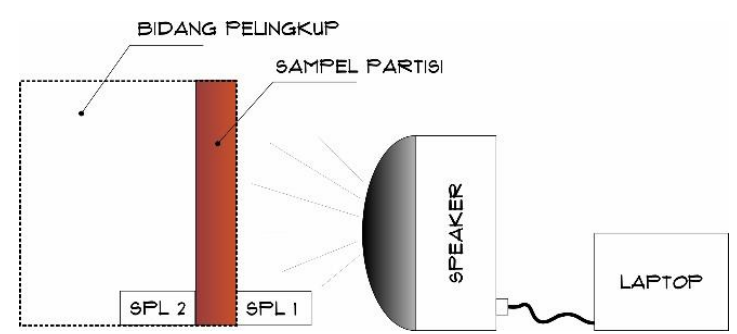

Gambar 14. Cara pengambilan data SPL 1 dan SPL 2 
Pengujian yang pertama dilakukan untuk satu lapisan berupa bingkai kain katun dan bingkai kain denim. Pengujian dapat dilihat dari Gambar 15 dibawah ini.

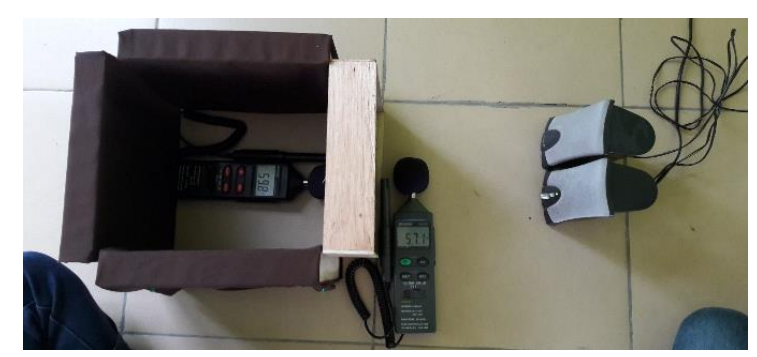

Gambar 15. Pengujian 1 lapisan

Selanjutnya dilakukan pengujian 2 lapisan yaitu kain dan denim yang digabungkan.

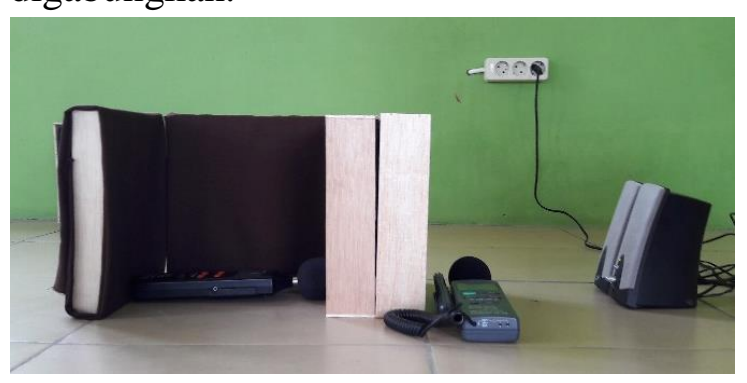

Gambar 16. Pengujian 2 lapisan

\section{HASIL DAN PEMBAHASAN}

Pengambilan data nilai SPL 1 dan SPL 2 untuk mendapatkan nilai NR menggunakan sumber suara berupa suara frekuensi 125, 250, 500, 1000, dan 2000 dengan nilai decibel awal adalah $100 \mathrm{~dB}$ sehingga background noise ruangan penelitian dapat tertutup oleh sumber suara.

Dengan menggunakan rumus NR maka didapatkan nilai NRnya. Nilai NR merupakan tingkat penurunan bunyi di dalam ruang yang bergantung pada bidang batas ruangan.

Setelah mendapat nilai NR pada setiap masing-masing data, selanjutnya dicari nilai rata-rata Noise Reduction (NR) yang merupakan hasil analisa dari Tabel 4.

Tabel 4. Hasil perhitungan rata-rata Noise Reduction (NR)

\begin{tabular}{lccccc}
\hline \multicolumn{7}{c}{ FREKUENSI (Hz) } \\
MATERIAL & $\mathbf{1 2 5}$ & $\mathbf{2 5 0}$ & $\mathbf{5 0 0}$ & $\mathbf{1 0 0 0}$ & $\mathbf{2 0 0 0}$ \\
\hline $\begin{array}{l}\text { 1 LAPISAN GEMPAL } \\
\text { denim }\end{array}$ & 11.93 & 6.01 & 12.83 & 12.13 & 9.40 \\
katun & 10.27 & 7.20 & 11.30 & 15.00 & 7.03 \\
$\begin{array}{l}\text { 2 LAPISAN GEMPAL } \\
\text { denim + }\end{array}$ & 14.90 & 8.07 & 10.20 & 25.20 & 15.53 \\
katun & & & & & \\
\hline
\end{tabular}

Dari Tabel 4, kain memiliki perubahan tingkat bunyi berkisar antara 6 dB sampai dengan $15 \mathrm{~dB}$. Menurut Satwiko (Satwiko, P., 2004) perubahan bunyi antara 3 sampai $20 \mathrm{~dB}$ memiliki efek yang dapat dirasakan manusia. Dari teori dan hasil pengujian kain, baik kain berbahan katun maupun denim dapat menurunkan bunyi rata-rata sampai dengan $10-14 \mathrm{~dB}$

Tabel 3. Data Pengujian Intensitas bunyi

\begin{tabular}{|c|c|c|c|c|c|c|c|c|c|c|c|c|c|c|c|c|c|}
\hline \multirow[b]{2}{*}{ No. } & \multirow[b]{2}{*}{ SAMPEL Uلا } & \multirow[b]{2}{*}{ Exp } & \multicolumn{3}{|c|}{$125 \mathrm{HZ}$} & \multicolumn{3}{|c|}{$250 \mathrm{HZ}$} & \multicolumn{3}{|c|}{$500 \mathrm{HZ}$} & \multicolumn{3}{|c|}{$1 \mathrm{KHZ}$} & \multicolumn{3}{|c|}{$2 \mathrm{KHZ}$} \\
\hline & & & $\begin{array}{l}\text { SPL } 1 \\
\text { (dB) }\end{array}$ & $\begin{array}{l}\text { SPL } 2 \\
\text { (dB) }\end{array}$ & $\begin{array}{l}\text { NR } \\
\text { (dB) }\end{array}$ & $\begin{array}{l}\text { SPL } 1 \\
\text { (dB) }\end{array}$ & $\begin{array}{l}\text { SPL } 2 \\
\text { (dB) }\end{array}$ & $\begin{array}{l}\text { NR } \\
\text { (dB) }\end{array}$ & $\begin{array}{l}\text { SPL } 1 \\
\text { (dB) }\end{array}$ & $\begin{array}{l}\text { SPL } 2 \\
\text { (dB) }\end{array}$ & $\begin{array}{l}\text { NR } \\
\text { (dB) }\end{array}$ & $\begin{array}{l}\text { SPL } 1 \\
\text { (dB) }\end{array}$ & $\begin{array}{l}\text { SPL } 2 \\
\text { (dB) }\end{array}$ & $\begin{array}{l}\text { NR } \\
\text { (dB) }\end{array}$ & $\begin{array}{l}\text { SPL } 1 \\
\text { (dB) }\end{array}$ & $\begin{array}{l}\text { SPL } \\
\text { (dB) }\end{array}$ & $\begin{array}{l}\text { NR } \\
\text { (dB) }\end{array}$ \\
\hline \multirow[t]{3}{*}{1} & Varian I-denim & 1 & 93.9 & 82.5 & 11.4 & 91.7 & 85.9 & 5.8 & 100.8 & 87.9 & 12.9 & 92.1 & 80.9 & 11.2 & 98.5 & 88.7 & 9.8 \\
\hline & & 2 & 94.5 & 81.7 & 12.8 & 91.3 & 85.2 & 6.1 & 100.9 & 88.4 & 12.5 & 93.2 & 79.5 & 13.7 & 98.9 & 89.5 & 9.4 \\
\hline & & 3 & 94.1 & 82.5 & 11.6 & 90.5 & 84.4 & 6.1 & 101.2 & 88.1 & 13.1 & 92.5 & 81.0 & 11.5 & 98.6 & 89.6 & 9.0 \\
\hline \multirow[t]{3}{*}{2} & Varian I - katun & 1 & 93.6 & 83.5 & 10.1 & 91.7 & 84.0 & 7.7 & 100.7 & 89.2 & 11.5 & 93.7 & 79.7 & 14.0 & 100.4 & 91.4 & 9.0 \\
\hline & & 2 & 93.5 & 83.6 & 9.9 & 91.7 & 85.2 & 6.5 & 100.7 & 89.7 & 11.0 & 93.5 & 74.7 & 18.8 & 99.9 & 91.9 & 8.0 \\
\hline & & 3 & 94.3 & 83.5 & 10.8 & 91.8 & 84.4 & 7.4 & 100.7 & 89.3 & 11.4 & 93.3 & 81.1 & 12.2 & 97.0 & 92.9 & 4.1 \\
\hline \multirow[t]{3}{*}{3} & Varian I-denim + katun & 1 & 95.3 & 80.0 & 15.3 & 92.5 & 84.1 & 8.4 & 98.8 & 88.8 & 10.0 & 96.2 & 71.0 & 25.2 & 99.7 & 84.4 & 15.3 \\
\hline & & 2 & 95.3 & 79.9 & 15.4 & 92.5 & 84.3 & 8.2 & 98.8 & 88.8 & 10.0 & 96.0 & 70.5 & 25.5 & 100.2 & 84.5 & 15.7 \\
\hline & & 3 & 94.6 & 80.6 & 14.0 & 92.8 & 85.2 & 7.6 & 99.4 & 88.8 & 10.6 & 96.0 & 71.1 & 24.9 & 100.6 & 85.0 & 15.6 \\
\hline
\end{tabular}


yang berarti efek suara dari sumber suara ke ruang penerima dapat dirasakan dua kali lebih lemah dari bunyi awal.

Pada grafik Noise Reduction (NR) secara umum material denim maupun kain katun yang dibuat berbentuk gempal efektif pada frekuensi-frekuensi tertentu.

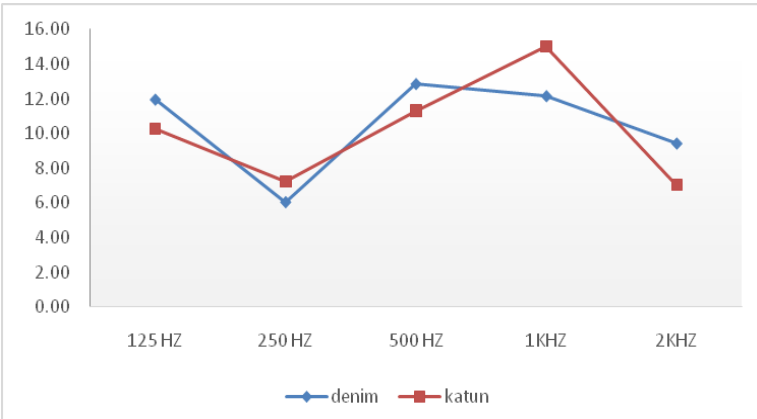

Gambar17. Grafik NR Variasi Partisi Kain Perca gempal 1 Lapisan terhadap frekuensi

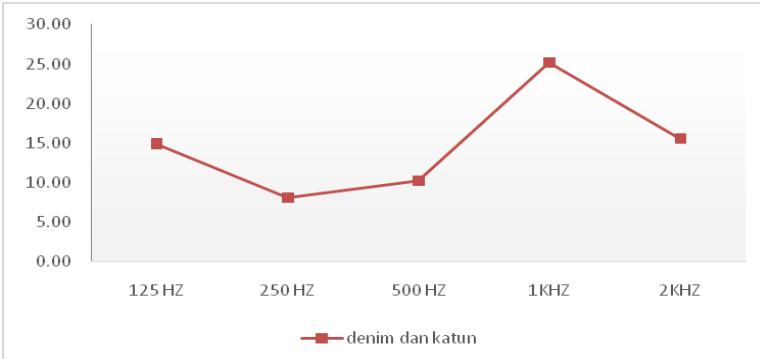

Gambar 18. Grafik NR Variasi Partisi Kain Perca gempal 2 Lapisan terhadap frekuensi

Gambar 17 memperlihatkan bahwa pada sampel 1 lapisan bahan gempal kain katun dan bahan gempal denim efektif dalam meredam suara pada frekuensi $500 \mathrm{~Hz}$ dan $100 \mathrm{~Hz}$. Selanjutnya dari gambar 18 , pada sampel 2 lapisan sekat efektif meredam suara pada frekuensi $1000 \mathrm{~Hz}$ dan $2000 \mathrm{~Hz}$.

Hasil tersebut menunjukkan bahwa sekat berupa gempal kain denim maupun kain katun mampu meredam suara yang berasal dari suara manusia dalam lingkup rumah tinggal di mana percakapan manusia memiliki frekuensi sekitar $1000 \mathrm{~Hz}$ (Rahmi, 2009).

\section{KESIMPULAN DAN SARAN}

\section{Kesimpulan}

Sekat dengan lapisan gempal berbahan kain katun lebih efektif dalam meredam suara dibanding sekat lapisan gempal berbahan kain denim karena pada kain denim lebih mampu mengurangi kebisingan ruangan yang berasal dari suara manusia $(1000 \mathrm{~Hz})$.

Sekat dengan 2 lapisan gempal berbahan kain denim dan kain katun yang digabungkan dapat efektif mereduksi suara 2 kali bunyi asli pada frekuensi tinggi yaitu $1000 \mathrm{~Hz}$ dan $2000 \mathrm{~Hz}$.

Antara 2 macam variasi lapisan yang paling efektif dalam meredam suara yaitu sekat dengan 2 lapisan gempal. Sekat dengan lapisan gempal berbahan kain denim dan berbahan kain katun dapat menjadi produk interior skala rumah tangga dengan sumber suara $1000 \mathrm{~Hz}$ sampai dengan 2000 $\mathrm{Hz}$.

\section{Saran}

Penelitian ini mampu dikembangkan untuk penelitian lebih lanjut. Cara pengolahan kain sebagai sekat berpotensi untuk digunakan sebagai panel akustik dengan pemanfaatan limbah industri tekstil. Panel akustik dari gempal kain (denim dan katun) dapat memberikan efek akustik karena permukaannya yang tidak rata dan mampu membaurkan bunyi.

\section{DAFTAR PUSTAKA}

Egan, M.D. (1972). Concepts IN Architectural Acoustics. New York: McGraw-Hill Inc.

Febrian, Sugiarto, Sudjarwo, \& Buntoro. (2012). Material Peredam Suara dengan Menggunakan Kombinasi Damen, Serabut Kelapa, dan Dinding Bata, 1(1).

KNLH. (2008). Statistik Persampahan Domestik Indonesia. Retrieved from 
http://dokumen.tips/documents/statisti k-persampahan-indonesia-2008.html

Mediastika, C. E. (2005). Akustika Bangunan, Prinsip-Prinsip dan Penerapannya di Indonesia. Jakarta: Erlangga.

Nico N. S., A. (2007). Karakteristik Koefisien Absorbsi Suara dari Panel Kain. Bandung: Departemen Teknik Fisika ITB.

Papanek, V. (1995). The Green Imperative: Ecology and Ethics in Design and Architecture. Singapore: C.S. Graphics.
Priyanti. (2013). Cerdik Berkreasi dengan Perca Batik. Yogyakarta: Andi.

Rahmi, A. (2009). Analisis Hubungan Tingkat Kebisingan dan Keluhan Subjektif (Non Auditory) Pada Operator SPBU di DKI Jakarta Tahun 2009 (Tesis). Universitas Indonesia, Jakarta.

Satwiko, P. (2004). Fisika Bangunan 1 (1st ed.). Yogyakarta: Andi. 
154 | Dinamika Kerajinan dan Batik, Vol. 33, No. 2, Desember 2016, 145-154 